\title{
Breast reconstruction with autologous tissue following mastectomy: two case reports of a delayed conventional transverse rectus abdominismyocutaneous (TRAM) and latissimus dorsi myocutaneous (LDM) flap surgery
}

\author{
Rosadi Seswandhana, Aditya Wicaksana, Siti Isya Wahdini, Ishandono Dachlan \\ Plastic, Reconstructive, and Aesthetic Surgery Division, Department of Surgery, Faculty \\ of Medicine Public Health and Nursing, Universitas Gadjah Mada/Dr. Sardjito Hospital, \\ Yogyakarta, Indonesia
}

DOI: http://dx.doi.org/10.19106/JMedScie/005004201813

\section{ABSTRACT}

Breast cancer is the most common malignant tumor and the leading cause of death among females. Most women with breast cancer will undergo breast-conserving surgery (BCS) or lumpectomy, simple or total mastectomy, modified radical mastectomy or bilateral mastectomy. Breast reconstruction solves many of the problems. The goal is to return the patient to a near-normal state so that she is not handicapped in her daily living. Breast reconstruction is also intended to offer psychological benefits to women treated by mastectomy following a diagnosis of possibly terminal cancer. In these case reports, we reported two successful cosmetic reconstruction cases. The first case was a 39-yearsold female with non-recurrent breast cancer consulted and was referred by the oncology surgeon to the Plastic Reconstructive, and Aesthetic Surgery Division, Department of Surgery, Dr. Sardjito General Hospital. She wanted to undergo breast reconstruction. We planned to operate three years following mastectomy. She was diagnosed with 3B-stage of right breast cancer before. After the surgery, the patient received six series of chemotherapy. She also underwent radiotherapy 25 times and hormonal therapy. We decided to perform a transverse rectus abdominis myocutaneous (TRAM) flap surgery on her with 22 months follow up. The procedure provided good results, and the patient was satisfied. The second case was a 32-year-old woman who after excision of a phyllodes tumor and wanted breast reconstruction. Reconstruction was performed four years after tumor removal using latissimus dorsi myocutaneous (LDM) flap. The surgery provided good results, and the patient was satisfied. We reported two successful cosmetic reconstruction cases of non-recurrent 3B-stage of right breast cancer post-mastectomy after pedicled TRAM flap surgery and left breast post excision of phyllodes tumor after LDM flap surgery.

\section{ABSTRAK}

Kanker payudara adalah tumor ganas yang paling umum dan merupakan penyebab utama kematian pada wanita. Sebagian besar wanita dengan kanker payudara akan menjalani bebeapa jenis operasi yang melibatkan operasi pengangkatan tumor atau lumpektomi, mastektomi simpel atau total, mastektomi radikal yang dimofidikasi dan mastektomi bilateral. Rekonstruksi payudara dapat mengatasi masalah akibat mastektomi dan bertujuan mengemballikan kondisi pasien mendekati normal sehingga tidak mengalami disabilitas dalam kehidupan sehari-hari. Rekonstruksi payudara juga dimaksudkan untuk menawarkan manfaat psikologis bagi wanita yang diobati dengan mastektomi setelah diagnosis kemungkinan kanker stadium akhir. Pada laporan kasus ini, dilaporkan keberhasilan dua kasus rekonstruksi payudara. Kasus pertama adalah seorang wanita berusia 39 tahun dengan kanker payudara non-rekuren berkonsultasi untuk dilakukan 
rekonstruksi payudara ke Divisi Bedah Plastik, Rekonstruksi, dan Estetika, Departemen Bedah, RSUP Dr. Sardjito, Yogyakarta. Rekonstruksi payudara direncanakan tiga tahun setelah mastektomi. Pasien terdiagnosis dengan kanker payudara stadium 3B sebelum mastektomi. Setelah mastektomi, pasien menjalani enam seri kemoterapi dan 25 seri radioterapi serta terapi hormonal. Pasien menjalani prosedur transverse rectus abdominis myocutaneous (TRAM) flap ditindak lanjuti selama 22 bulan. Operasi berhasil dengan baik dan pasien puas dengan hasil rekonstruksi. Kasus kedua adalah wanita berusia 32 tahun paska eksisi tumor phyllodes, pasien menginginkan rekonstruksi payudara. Rekonstruksi dilakukan 4 tahun setelah eksisi tumor dengan prosedur latissimus dorsi myocutaneous (LDM) flap. Operasi berhasil dengan baik dan pasien puas. Kami telah melaporkan keberhasilan dua kasus rekonstruksi kanker payudara stadium 3B non-rekuren post mastektomi setelah menjalani bedah TRAM flap dan tumor filoides post eksisi setelah menjalani bedah LDM flap.

\section{Keywords: breast reconstruction - autologous - pedicled TRAM flap - LDM flap - plastic surgery}

\section{INTRODUCTION}

Breast cancer is the most common cancer worldwide and one of the leading causes of cancer mortality in the female population. ${ }^{1}$ Breast cancer accounted for 2,088,849 new cases (11.6\% of all cancers) and 626,679 (6.6\% of all cancers) death. ${ }^{1}$ There were 2.1 million new breast cancer cases in 2018 worldwide, responsible for almost 1 in 4 cases among female. ${ }^{1}$ The incidence of breast cancer varies among the population. In Indonesia, the incidence is about 48,998, ${ }^{2}$ in Europe and North America, the incidence is between 70 up to 100 new cases in 100,000 per year. ${ }^{3,4}$

Women who were diagnosed with earlystage breast cancer may undergo surgery combined with other treatments to reduce the risk of recurrence, such as chemotherapy, radiotherapy, and/or hormonal/endocrine therapy. Surgical treatment for breast cancer usually involves breast-conserving surgery (lumpectomy) and mastectomy (simple or total mastectomy and modified radical mastectomy). ${ }^{4}$

Mastectomy may bring psychological impacts, which include fear of cancer, feelings of emptiness, inconvenience in working and communicating socially, less sexual desire and low spirit. ${ }^{5}$ Breast reconstruction is a multidisciplinary approach that not only provides the safest possibilities into account but also aesthetically satisfies the patient and prevents possible late complications. ${ }^{6}$ Breast reconstruction is aimed to offer psychological benefits (to improve the quality of life, body image, sense of integrity and selfimage) to women who undergo mastectomy following diagnosis of breast cancer. Breast reconstruction may help to restore women's psychological and emotional well-being. ${ }^{5}$

Plastic surgeons mostly do the use of autologous tissue for breast reconstruction following mastectomy. This is because autologous breast reconstruction will last permanently. There are many variations of donor sites for autologous reconstruction, one of which is transverse rectus abdominis musculocutaneous (TRAM) and latissimus dorsi musculocutaneous (LDM) flap. These flaps contain skin, fat tissue, and muscles that are transferred to the vascularized pedicle. ${ }^{7}$

We reported two cases involving a 39-year-old female with non-recurrent 3B-stage right breast cancer post mastectomy three years ago and a 32-year-old woman after excision of a phyllodes tumor. We performed conventional (pedicled) TRAM flap surgery for the delayed breast reconstruction and followed the patient for twenty-two months and LDM flap surgery for the post excision of the phyllodes tumor. 


\section{CASES REPORT}

\section{Case 1}

A39 years old female who presented with non-recurrentbreastcancerwas consulted and referred by the oncology surgeon. The patient wanted to undergo breast reconstruction as she felt unconfident thus being limited in engagement in usual activities. We performed breast reconstruction three years following mastectomy. She was diagnosed with 3B-stage of right breast cancer before undergoing mastectomy. After undergoing the right mastectomy, the patient received adjuvant chemotherapy for six series. She also underwent radiotherapy twenty-five times, and also consumes hormonal therapy. She had an Orr-type of mastectomy scar with a slightly protruding stomach (FIGURE 1). Written informed consent was obtained from the patient who participated in this case.

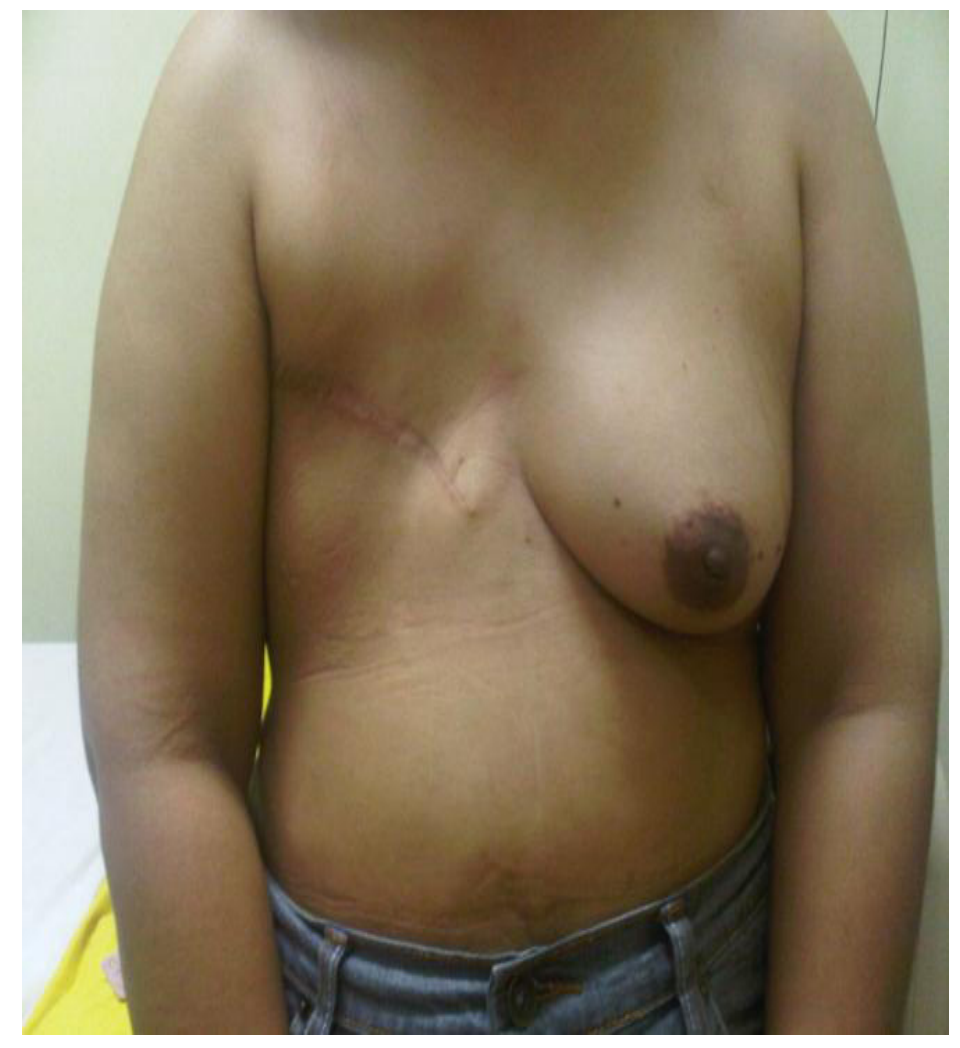

FIGURE 1. The state of the patient before breast reconstruction with an Orr-type mastectomy scar

Before the reconstruction, we assessed the psychological aspects of the patient to develop a conducive relationship to plan the stages of reconstruction to meet the patient's needs. 


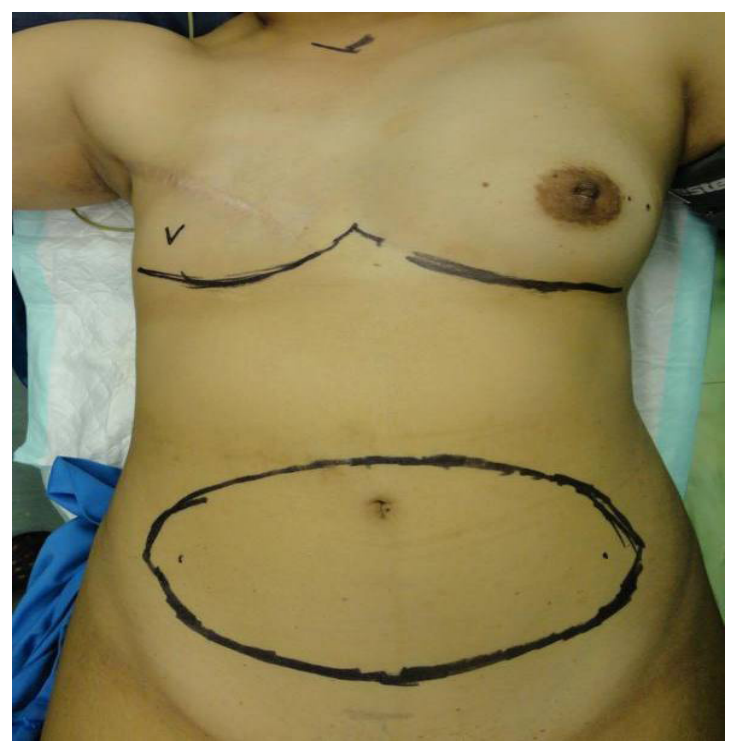

FIGURE 2. The patients was marked and prepared before the procedure

Some stages of the reconstruction surgery were performed to meet the patient's specific wishes. The first phase of the surgery was to set up a breast mass using a conventional TRAM flap. TRAM flap was chosen because of the extensive fatty tissue present, and the conventional method was chosen because the patient was quite young with good vascular quality.

The skin island for TRAM flap was typically taken from skin between umbilicus, pubic region, and front of the iliac bone. Skin and fat tissue were supplied by perforators over the rectus abdominis muscle. The deep, superior and inferior epigastric vessels supplied the muscle. After that step, the flap was placed upwards to the mastectomy site while still connected to the rest of the muscle (FIGURE 3). The abdomen was reconstructed using fascial duplication of the rectus abdominis muscle sheath, as well as using epifascial decrease at the abdominal wall cranial of the umbilicus.
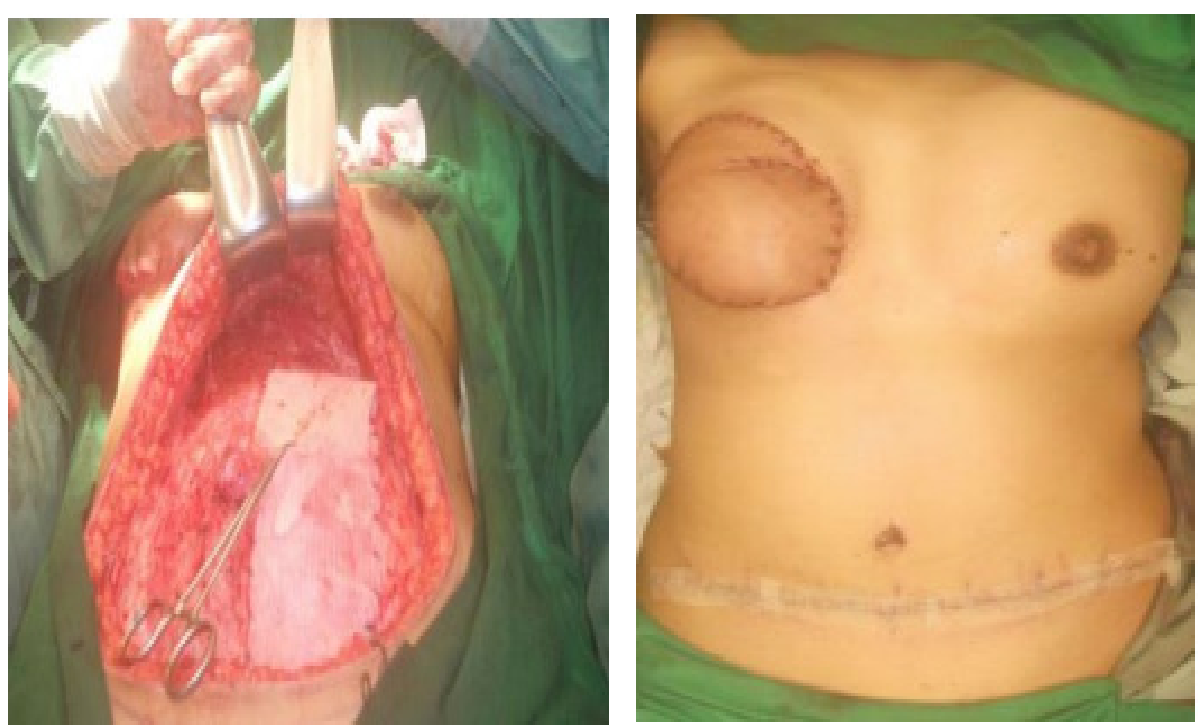

FIGURE 3. Tunneling and inserting flap 
In the first week following the TRAM procedure, the wound was clean and dry (FIGURE 4). However, in the first 14 days after TRAM flap procedure, the wound underwent dehiscence on the craniolateral edge of the flap (FIGURE 5). We treated it conservatively and the wound recovered after one week of wound care.

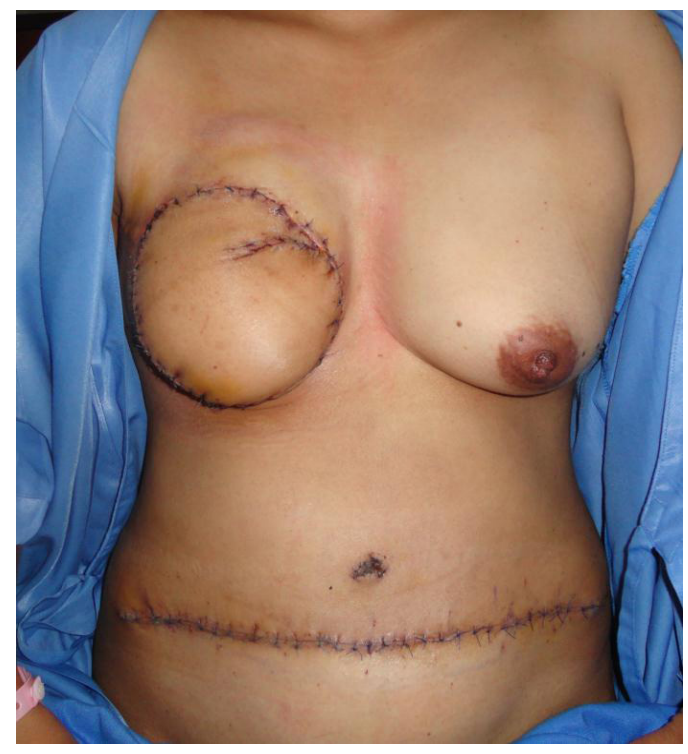

FIGURE 4. A week following the TRAM procedure

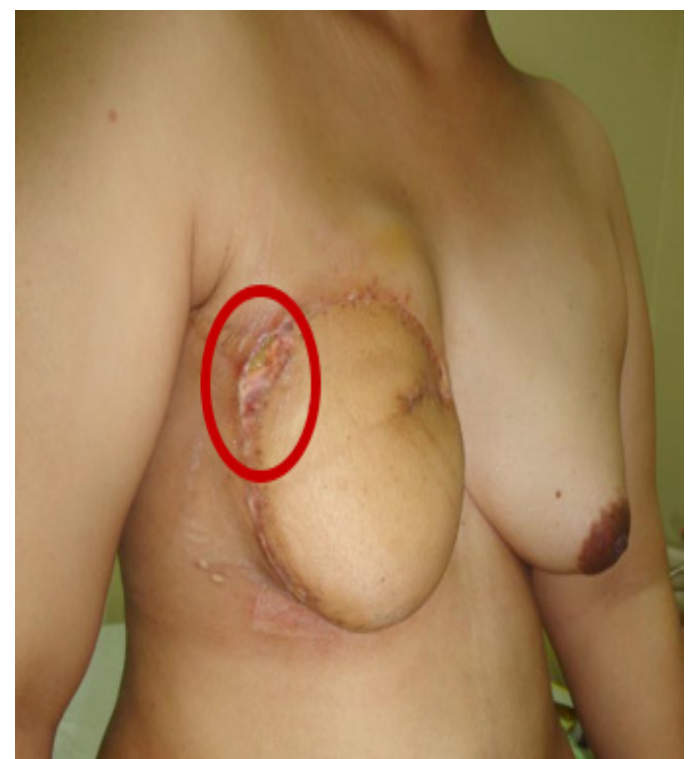

FIGURE 5. Fourteen days following TRAM procedure, there was wound dehiscence in the craniolateral aspect of the flap

Three months after the first surgery, we found a solid mass in the cranial aspect of the TRAM flap (FIGURE 6). Fine needle aspiration (FNA) examination was performed to confirm whether breast cancer recurrence occurred. It results showed no malignant cells and only found inflammatory cells. We treated the inflammation in the surgical wounds conservatively. After nine months of conservative therapy, the solid mass on the cranial part of the flap became smaller and softer (FIGURE 7). 


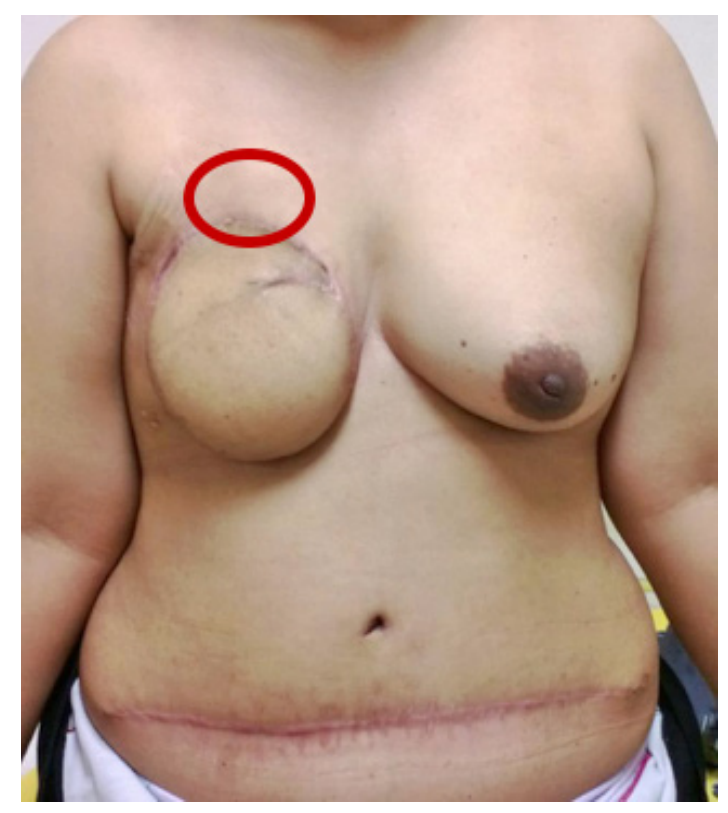

FIGURE 6. Three months following TRAM procedure, a $5-\mathrm{cm}$ solid mass was palpable in the cranial aspect of TRAM flap

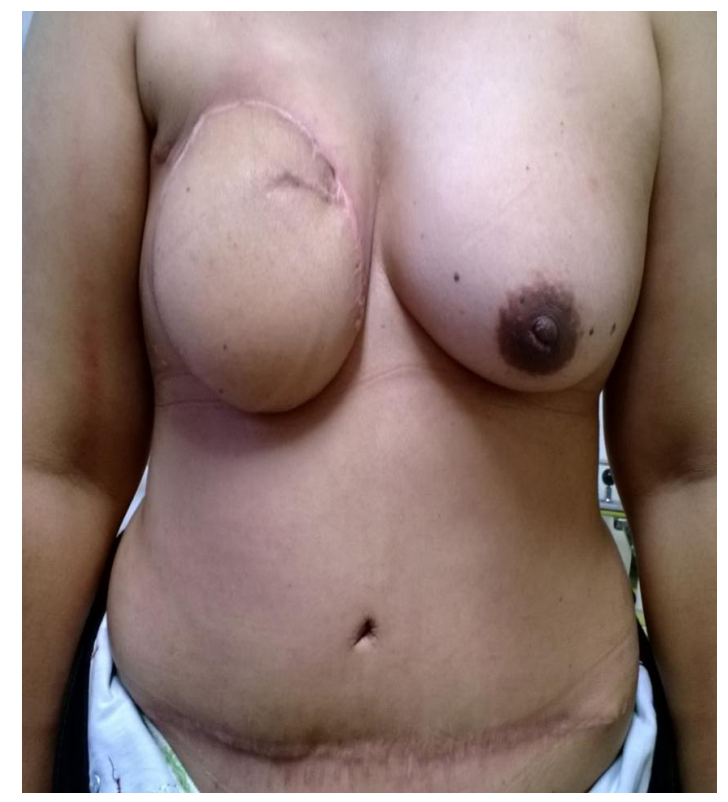

FIGURE 7. Nine months following the TRAM procedure, the palpable mass became smaller and softer

Nipple-areola complex colouring was performed one year after TRAM using a full thickness skin graft (FTSG) technique because the patient did not want to have a tattooing procedure (FIGURE 8). We reconstructed the nipple using a modified double-opposing tab flap 18 months following TRAM (FIGURE 9). 


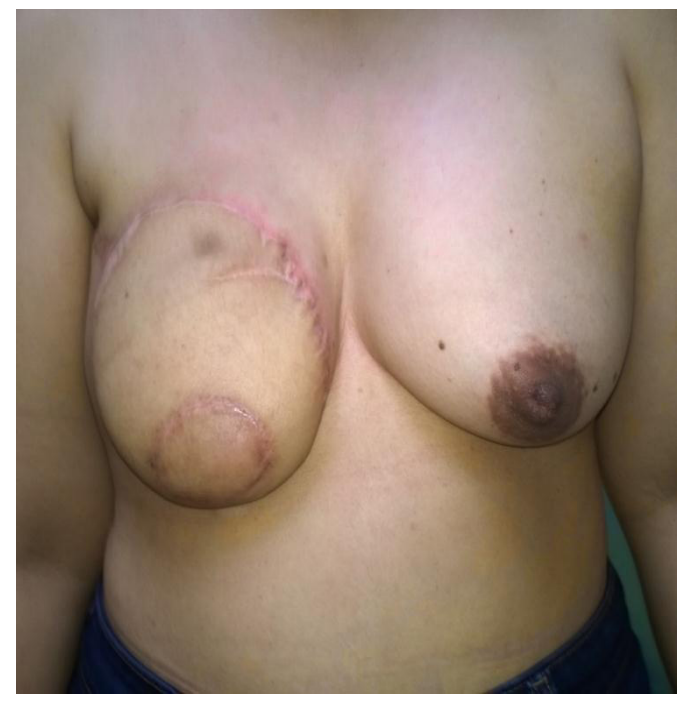

FIGURE 8. Nipple-areola complexcolouring and reconstruction with expendablefull-thickness skin graft.
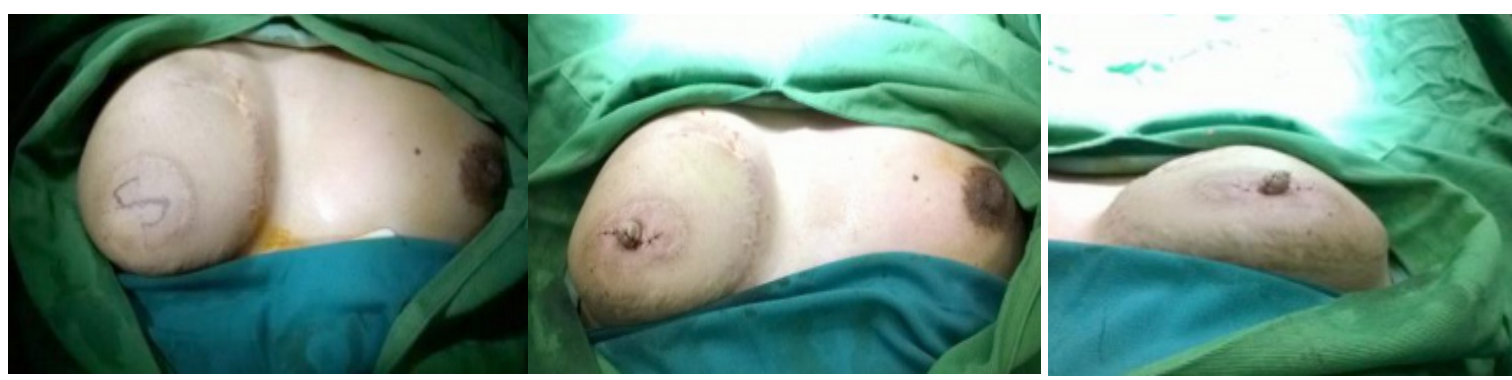

FIGURE 9. Reconstruction of the nipple with modified double-opposing tab flap was performed eight months following the first TRAM procedure.

After 22 months following TRAM, reconstruction (FIGURE 10). the patient was satisfied with the result of the
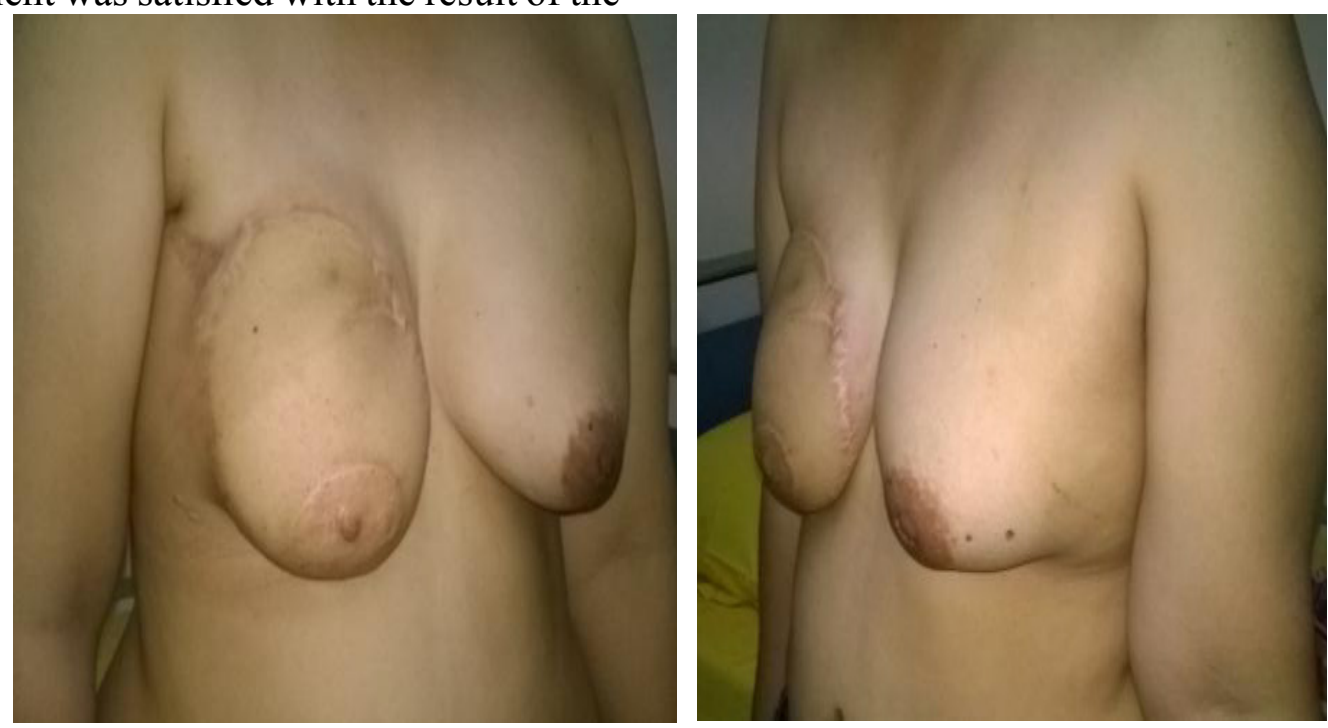

FIGURE 10. The result of twenty-two months' follow-up from the first TRAM procedure and five months following nipple reconstruction, the patient was quite satisfied with the results of the reconstruction. 


\section{Case 2}

A 32-year-old female presented as an outpatient asking for breast reconstruction. She wanted to do so because she had been limiting herself in social activities as she did not confident of her physical appearance. The patient had a history of phyllodes tumor excision on the left breast four years prior. We performed breast reconstruction using a latissimus dorsi myocutaneous (LDM) flap. This method was chosen because the right breast was not large, so there was no need for a big flap. Written informed consent was also obtained from the patient who participated in this case.

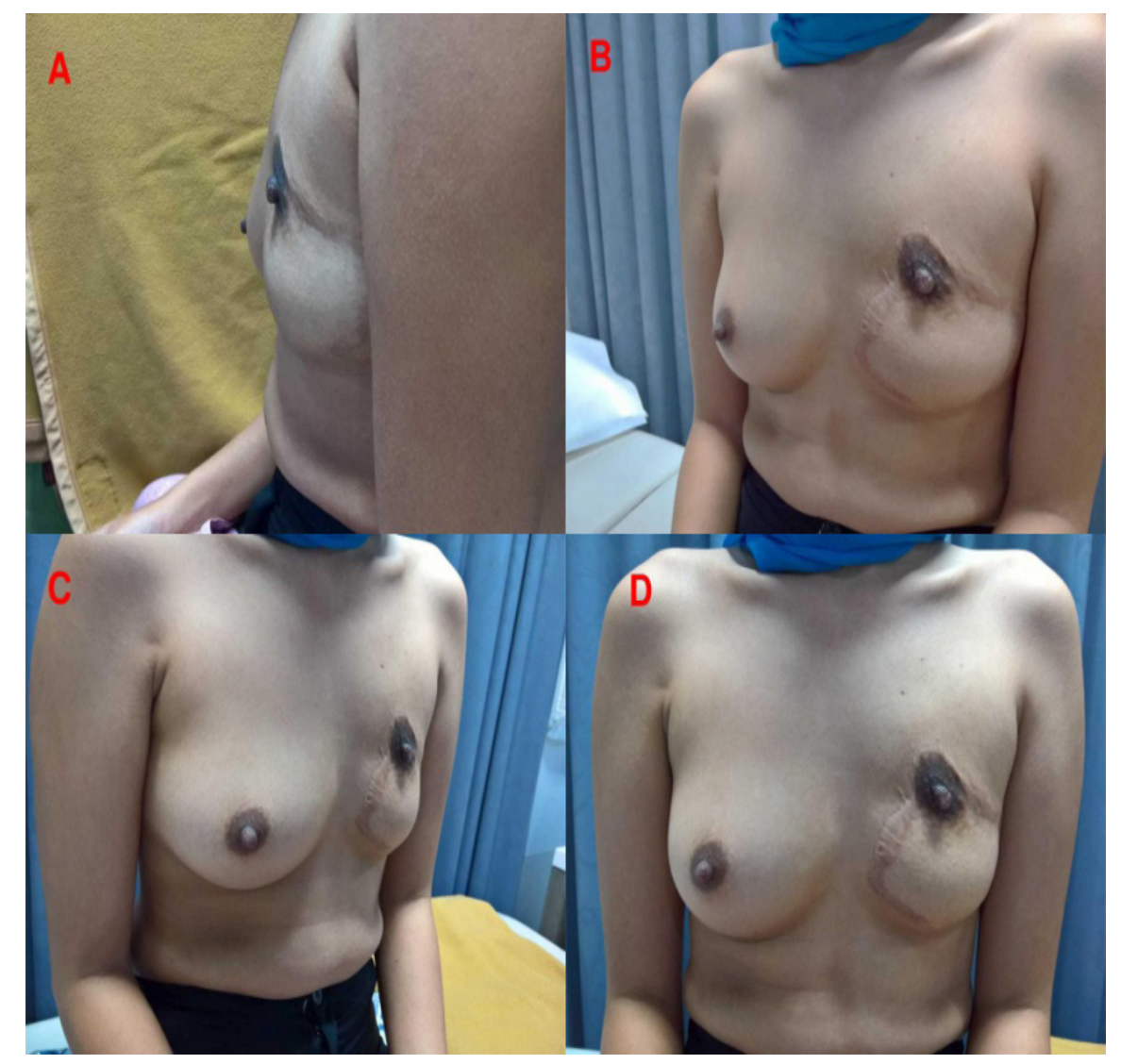

FIGURE 11. The state of the patientbefore breast reconstruction (A). Lateral view of the breast; (B). Left oblique view of the breast; (C). Right oblique view of the breast; (D). Anterior view of the breast.

The first phase of the surgery was to set up a breast mass using the LDM flap procedure. The LDM flap procedure was chosen because the left side of the breast was mostly retained, and the size was not large, so there was no need of a big donor (FIGURE 11). Before the procedure, the patient was placed in sitting position, and the latissimus border was outlined with a marking pen (FIGURE 12). 


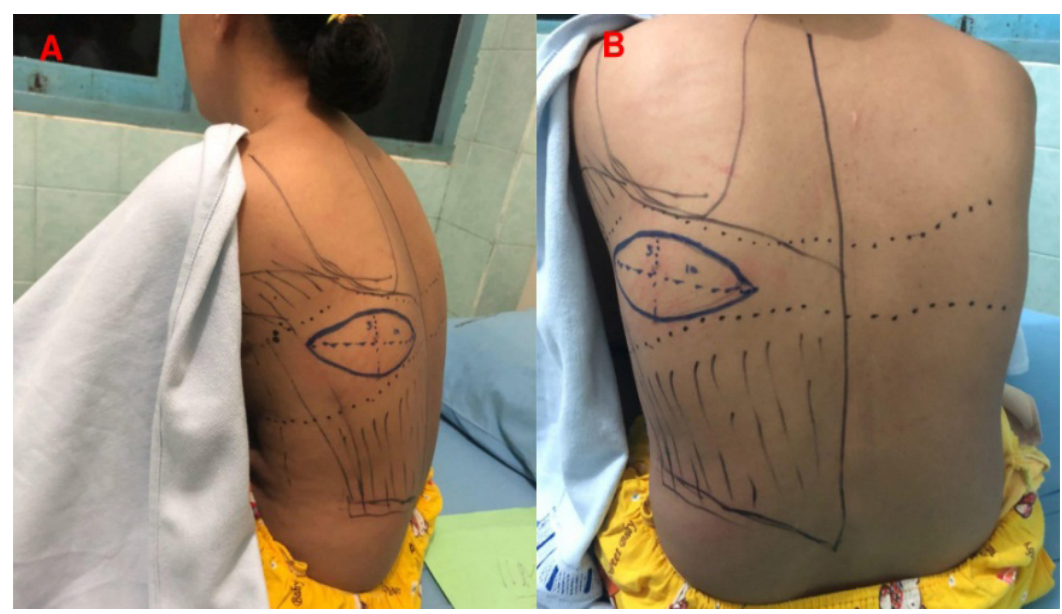

FIGURE 12. The patient was marked and prepped before the procedure

The bra strap would cover the postoperative wound. The Latissimus dorsi muscle was dissected, and the superior edge of the muscle was elevated and freed of medial and inferior attachments before the muscle harvest was then completed while the pedicle remained attached. Postoperative state of the patient can be seen in FIGURE 13-15. At the four months follow-up, there were neither infection, nor wound dehiscence and the patient was satisfied with the result (FIGURE 16).

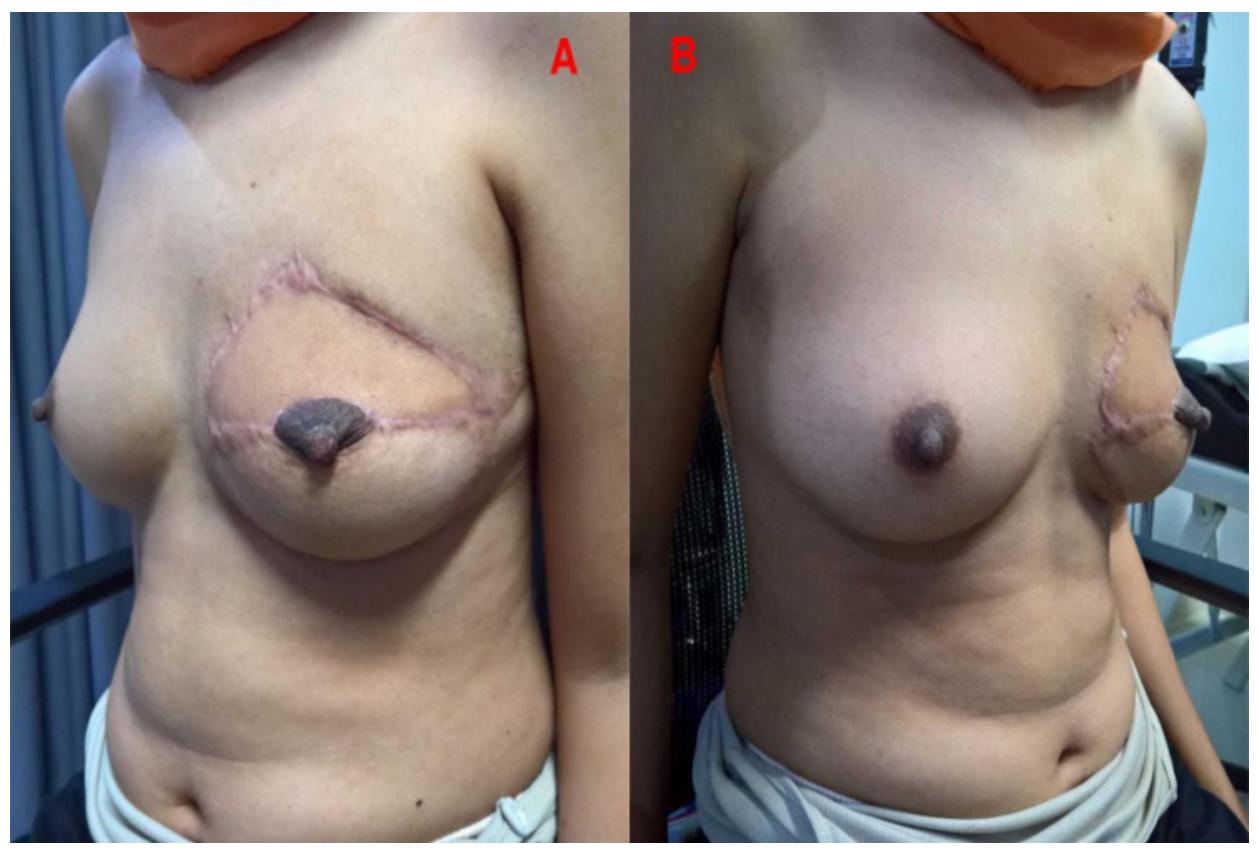

FIGURE 13. Post-operative state after breast reconstruction using latissimus dorsi flap on the left breast. (A). Left oblique view; (B). Right oblique view 


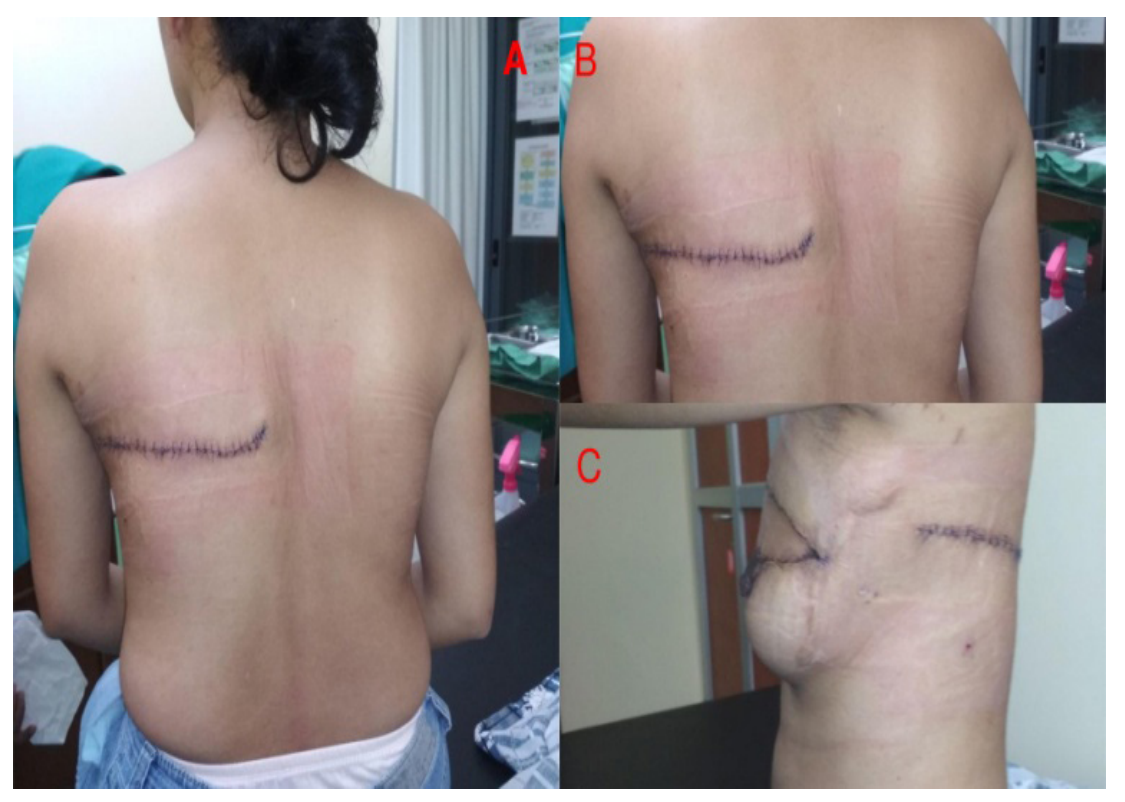

FIGURE 14. (A). Post-operative surgical wound. (B). Posterior oblique view; (C). Lateral view
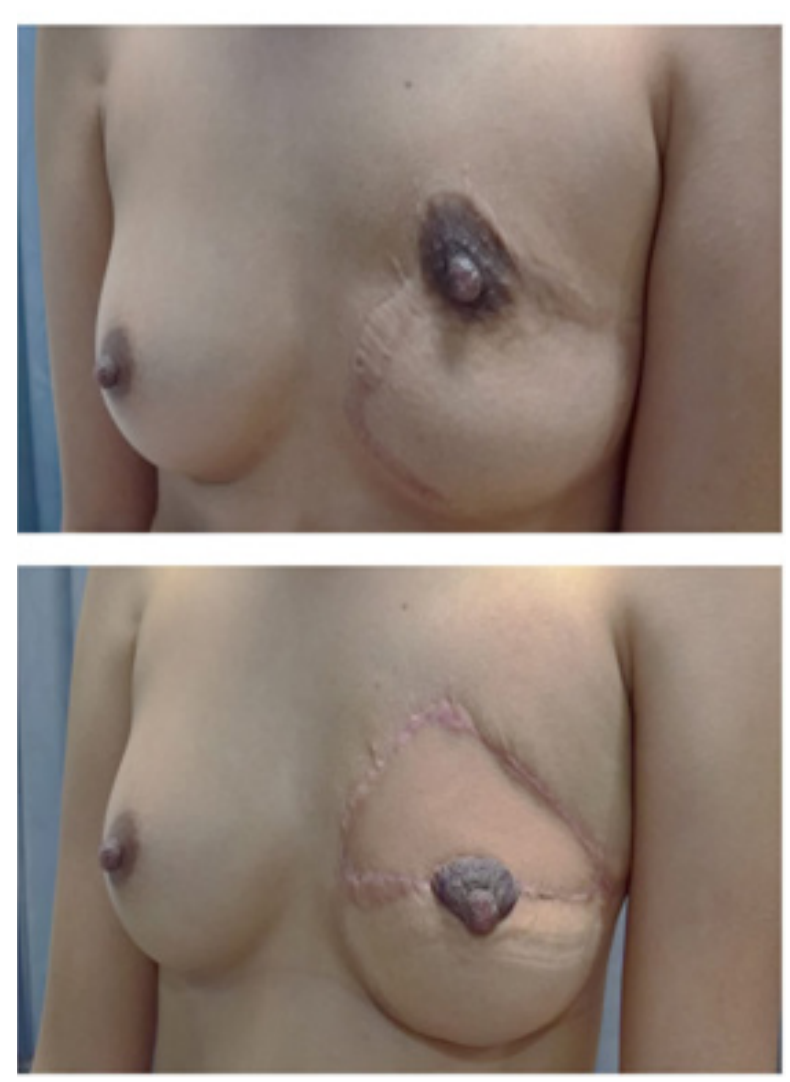

FIGURE 15. Comparison between preoperative and post-operative state. 


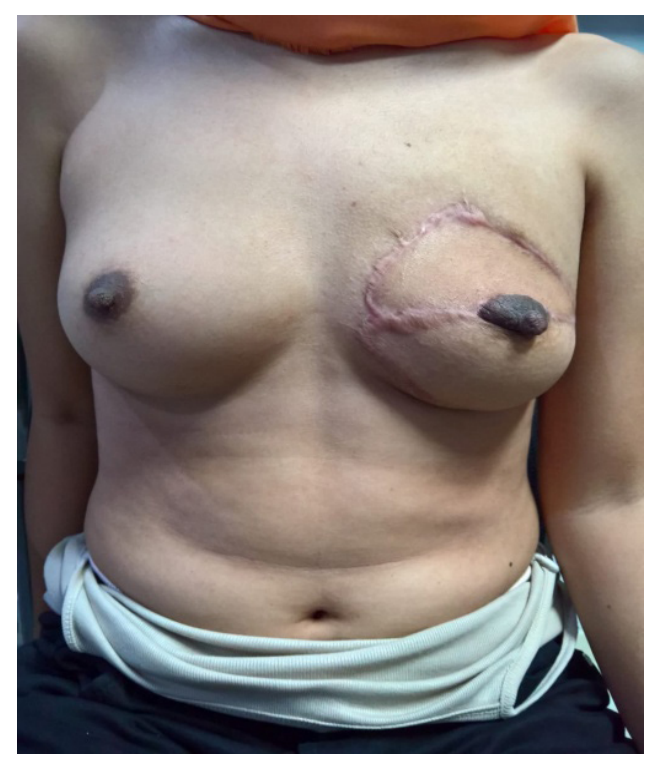

FIGURE 16. Four months follow up following LDM flap

\section{DISCUSSION}

Mastectomy is still the primary modality to obtain a high survival rate. Thus, the surgeon will also have to deal with the patient's psychological problems. Our patients considered a breast reconstruction surgery in three years following mastectomy and four years following excision of phyllodes tumor. They decided to undergo a breast reconstruction because they concerned about her aesthetic perfection and to cope with her appearance. They were also complaining about having limited social activities as they were not confident in their physical appearance. Thus, breast reconstructions were performed to meet patients' psychological and aesthetic demand

For most women, mastectomy is a mutilating and deforming surgical procedure that could damage a woman's self-image, leading to the patient questioning concerning her desirability as a sexual partner. ${ }^{5,8,9}$ Breasts are a symbol of femininity, and as a consequence, the loss of a breast can have severe psychological consequences. Some women may be withdrawn from relationships in which their deformity might be revealed or may withdraw from relationships with men and even other women. ${ }^{4}$ This withdrawal could be disadvantageous not only to the patient herself but her family, co-workers and anyone else related to her. For some women, the worry of a possible defect or deformity is significant enough to cause them to refuse surgery, although the absence of a breast can be easily camouflaged by clothing. ${ }^{4}$

Theoretically, the absence of a breast can be corrected merely by using a prosthesis. Regrettably, for many women, a prosthesis is considered an inadequate treatment. A woman who has undergone mastectomy without breast reconstruction is sometimes confronted by her deformity each time she undresses and is reminded that she is not only deformed but at risk for a cancer relapse. ${ }^{4}$ She also has limitations to dress up and may avoid activities such as swimming or dancing, which might cause the prosthesis to become displaced. Also, if the prosthesis is large, it may be uncomfortable, especially in a tropical or humid environment. ${ }^{4}$

Breast reconstruction is one of the modalities that could be performed to reduce psychological problems that arise in women who have undergone a mastectomy. Breast reconstruction is becoming more common in recent years, with the intention of restoring the shape of the breast into its natural shape in women who have undergone mastectomy. ${ }^{10}$ In order to achieve that result, some resources and coordination in medical 
teams are necessary, which unfortunately is not always the case, especially in Indonesia. A woman who has undergone a successful breast reconstruction can mostly wear almost all types of regular clothing so she can return actively and productively to her daily routine. ${ }^{4,11}$ A study showed that depression in the breast reconstruction group was less than for those women who had mastectomy alone. ${ }^{12}$ A prospective study of women who underwent delayed reconstruction found that preoperative expectations were met in $90 \%$ of the patients. ${ }^{12}$

Breast reconstruction began to enter the modern era with the application of the TRAM flap procedure by Hartrampf in 1982..$^{12,13}$ The main advantage of the procedure is that the reconstructed breast is identical to the natural breast in its softness and in the way the tissue covers the chest. If the TRAM flap procedure is applied adequately and carefully in the suitably selected patient, the TRAM flap procedure can be a safe and viable option with satisfactory outcome as well as providing a superior breast reconstruction to the other techniques. ${ }^{13}$

We decided to perform a conventional TRAM flap for the first case because the onset of the procedure was considerably delayed. The patient was psychologically motivated and had adequate tissues in the abdominal area (FIGURE 1).

After symmetry is achieved roughly six months after breast reconstruction, the nipple needs to be reconstructed in 3 to 6 months after achievement of symmetry. ${ }^{4} \mathrm{We}$ performed nipple reconstruction after 18 months following TRAM. Usually, an areola tattoo should be performed 4 to 6 weeks after nipple reconstruction, ${ }^{4}$ but in our case, the patient did not want to have an areola tattoo. Instead, we performed nipple-areola complexcoloring with FTSG1 year after TRAM.

The latissimus dorsi myocutaneous flap is also one of the most reliable and versatile flaps used in breast reconstruction surgery. It has the advantage of providing successful coverage of large soft tissue defects in the chest wall as in mastectomy for breast cancer. ${ }^{14,15}$ LDM flap provide good autologous tissue for breast reconstruction, especially for Asian women with small breasts, thus, no implants are needed. ${ }^{16}$

We decided to perform the LDM flap surgery for the second case because on the left side of the breast retained much of the mass of the breast, and the right breast was not large, so it did not require a thick donor (FIGURE 11).

Our experience showed that reconstruction was satisfying both physically and psychologically to the patients. Both of the patients felt more feminine and confident about their body. Therefore, they felt like having more self-esteem and confidence to be engaged in social activities and were feeling like "whole" again. The patients also felt the shape of the breast looks natural and similar to the normal breast. They did not experience pain both in the donor site or in the breast. Clinically, the skin of the flap also had good quality and was flexible as they were feeling the since it was not previously irradiated, and it allowed adequate tissue expansion, which remained over time.

\section{CONCLUSION}

Conventional TRAM flap and LDM flap reconstruction surgery for delayed breast reconstruction in a patient with 3B-stage breast cancer post mastectomy and post excision of phyllodes tumor show good outcomes both physically and psychologically.

\section{ACKNOWLEDGEMENTS}

We would like to thank the patients who have participated in this study.

\section{REFERENCES}

1. Bray F, Ferlay J, Soerjomataram I, Siegel RL, Torre LA, Jemal A. Global cancer statistics 2018: GLOBOCAN estimates 
of incidence and mortality worldwide for 36 cancers in 185 countries. CA Cancer J Cli 2018; 68(6):394-424. http://dx.doi.org/10.3322/caac.21492.

2. World Health Organization - Cancer Country Profiles, 2014.

3. Veronesi U, Boyle P, Goldhirsch A, Orecchia R, Viale G. Breast cancer. Lancet 2005; 365(9472):1727-41. http://dx.doi.org/10.1016/S0140-6736(05)66546-4

4. Teymouri HR, Stergioula S, Eder M, Kovacs L, Biemer E, Papadopulos NA. 2006. Breast reconstruction with autologous tissue following mastectomy. Hippokratia 2006; 10(4):153-62.

5. Nicholson RM, Leinster S, Sassoon EM. A comparison of the cosmetic and psychological outcome of breast reconstruction, breast conserving surgery and mastectomy without reconstruction. Breast 2007; 16(4):396-410. http://dx.doi.org/10.1016/j.breast.2007.01.009

6. Fertsch S, Munder B, Hagouan M, Schulz T, Thamm O, Stambera $P$, et al. Immediate-DElayed AutoLogous (IDEAL) Breast Reconstruction with the DIEP Flap. Chirurgia 2017; 112(4):387-93. http://dx.doi.org/10.21614/chirurgia.112.4.387

7. Nahabedian MY, Patel K. Autologous flap breast reconstruction: surgical algorithm and patient selection. J Surg Oncol 2016; 113(8):865-74.

http://dx.doi.org/ 10.1002/jso.24208.

8. Forbair P, Stewart SL, Chang S, D'Onofrio C, Banks PJ, Bloom JR. Body image and sexual problems in young women with breast cancer. Psychooncology 2006; 15(7):579-94. http://dx.doi.org/10.1002/pon.991

9. Di Saverio S, Catena F, Santini D, Ansaloni L, Fogacci T, Mignani S, et al. 259 Patients with DCIS of the breast applying USC/Van Nuys prognostic index: a retrospective review with long termfollow up. Breast Cancer Res Treat 2008; 109(3):405-16.

http://dx.doi.org/10.1007/s10549-007-9668-7
10. Kocan S, Gursoy A. Body image of women with breast cancer after mastectomy: a qualitative research. J Breast Heath 2016; 12:145-50. http://dx.doi.org/10.5152/tjbh.2016.2913

11. Rubino C, Figus A, Lorettu, Sechi G. Post-mastectomy reconstruction: a comparative analysis on psychosocial and psychopathological outcomes. J Plast Reconstr Aesthet Surg 2007; 60(5):509-18. http://dx.doi.org/10.1016/j.bjps.2006.06.013

12. Matthews H, Carroll N, Renshaw D, Turner A, Park A, Skillman J, et al. Predictors of satisfaction and quality of life following post-mastectomy breast reconstruction. Psychooncology 2017; 26(11):1860-65.

http://dx.doi.org/10.1102/pon.4397

13. Leyngold MM. Is unpedicled transverse rectus abdominis myocutaneous flap obsolete owing to superiority of DIEP flap? Ann Plast Surg 2018; 80(6S Suppl 6):S418-S420.

http://dx.doi.org/10.1097/SAP.0000000000001319

14. Kim JT, Kim SW, Youn S, Kim YH. What is the ideal free flap for soft tissue reconstruction?: a ten-year experience of microsurgical reconstruction using 334 latissimus dorsi flaps from a universal donor site. Ann Plast Surg 2015; 75(1):49-54. http:/dx.doi.org/10.1097/SAP.0000000000000010

15. Sood R, Easow JM, Konopka G, Panthaki ZJ. Latissimus dorsi flap in breast reconstruction: recent innovations the workhorse flap. Cancer Control 2018; 25(1):1073274817733638. http://dx.doi.org/ 10.1177/1073274817744638

16. Chiang IH, Wang $\mathrm{CH}$, Tzeng YS, Chiao HY, Chou CY, Wang CY, et al. Breast reconstruction using pedicled latissimus dorsi myocutaneous flaps in asian patients with small breasts. Ann Plast Surg 2017; 78(3 Supp1 2):S95-S101. http//dx.doi.org/10.1097/SAP.0000000000001013. 